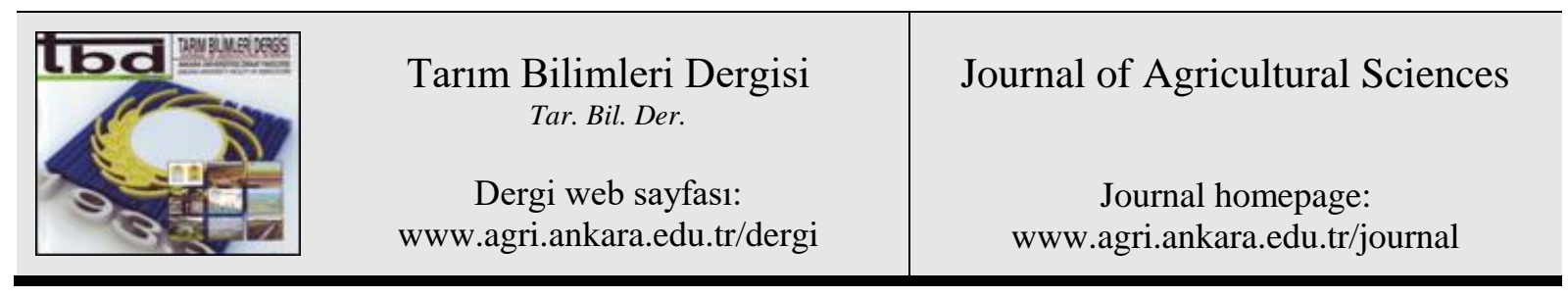

\title{
The Response of Braeburn Apple to Regulated Deficit Irrigation
}

\author{
Cenk KÜÇÜKYUMUK ${ }^{\mathrm{a}}$, Halit YILDIZ ${ }^{\mathrm{b}}$, M. Kamil MERIÇc

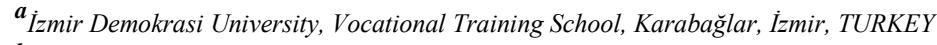 \\ $\boldsymbol{b}_{\text {Eğirdir Fruit Research Institute, Isparta, TURKEY }}$

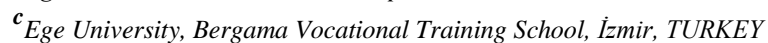

\author{
ARTICLE INFO \\ Research Article \\ Corresponding Author: Cenk KÜÇÜKYUMUK, E-mail: cenkkucukyumuk@ hotmail.com, Tel: +90 (533) 3474682 \\ Received: 03 December 2018, Received in Revised Form: 21 January 2019, Accepted: 27 February 2019
}

\section{AUTHORS ORCID ID}

(Cenk KÜÇÜKYUMUK: 0000-0002-0728-059X), (Halit YILDIZ: 0000-0001-7922-9366), (M. Kamil MERIÇ: 0000-0002-64154071)

\begin{abstract}
Regulated deficit irrigation (RDI) is one of deficit irrigation (DI) techniques and it is developed to minimize irrigation inputs in fruit production, especially in areas where water resources are limited, is recommended for saving irrigation water in agriculture. This study was conducted to determine the effects of deficit irrigation treatments applied in different growth periods on plant water consumption, water yield relations, stomatal conductance and yield of Braeburn apple variety (grafted on M9 rootstock). Experiments were conducted in the years 2010, 2011, and 2012 at Fruit Research Institute, Eğirdir, Isparta, Turkey. Six different irrigation treatments were applied as $\mathrm{I}_{1}$; non-deficit irrigation program, $\mathrm{I}_{2}$; continuous deficit irrigation program (CDI), $\mathrm{I}_{3}$; deficit irrigation program between the $40^{\text {th }}$ and $70^{\text {th }}$ days after full bloom (DAFB), $\mathrm{I}_{4}$; deficit irrigation program between the $70^{\text {th }}$ and $100^{\text {th }}$ DAFB, I5; deficit irrigation program
\end{abstract}

between the $100^{\text {th }}$ and $130^{\text {th }}$ DAFB and $\mathrm{I}_{6}$; deficit irrigation program between the $130^{\text {th }}$ and $160^{\text {th }}$ DAFB. The highest yield (55.2, 54.1 and $63.8 \mathrm{t} \mathrm{ha}^{-1}$ in 2010, 2011 and 2012 respectively) and water use efficiency (WUE) $\left(0.130,0.129\right.$ and $0.137 \mathrm{t} \mathrm{ha}^{-1}$ $\mathrm{mm}^{-1}$ in 2010, 2011 and 2012) values were obtained from $\mathrm{I}_{3}$ treatment in all short-term deficit irrigation treatments. The stomatal conductance values decreased during the short-term deficit irrigation treatments, but the values increased following the deficit irrigation periods. The results revealed that apple trees grafted on M9 rootstock were influenced by short-term water stress, but they were able to cope with stress after the deficit periods. In all deficit irrigation treatments, yield response factor (Ky) ranged from 0.77 to 2.11 Apple tree yield was less sensitive to water deficit in $\mathrm{I}_{3}$ compared to other treatments. Therefore $\mathrm{I}_{3}$ treatment was found to be applicable in case of scarce water resources since it ensured water saving.

Keywords: Apple; Regulated deficit irrigation; Stomatal conductance; Ky

(C) Ankara Üniversitesi Ziraat Fakültesi

\section{Introduction}

The available water resources used for agricultural production in the world is decreasing, so we need to increase water-use efficiency in agricultural practices (Naor et al 2008). The highest evapotranspiration rates occur during the dry seasons in Mediterranean areas (especially in summer months), it caused severe water deficit conditions. During those months crop irrigation becomes critical for those reasons (Lo Bianco et al 2012). Many studies have been conducted on its such as partial rootzone drying (PRD), regulated deficit irrigation, whole deficit irrigation etc. (Van Hooijdonk et al 2004; Talluto et al 2008; Lo Bianco \& Francaviglia 2012).

For saving irrigation water, deficit irrigation (DI) strategies are recommended without a remarkable reduction in yield for irrigated fruit trees. In fruit production, RDI is also a technique that is developed to minimize irrigation inputs, especially in areas where water resources is limited (Talluto et al 2008). A strategy to use regulated water 
deficits and reduced wetted root volume, with appropriate timing, would be useful in arid apple-growing regions to promote partitioning of metabolites that would favor fruiting in apple trees. The same information would be useful for formulating irrigation strategies when water supplies are inadequate (Ebel et al 1995). However, this approach requires clear information: 1 - What are responses of fruit trees to water stress at different growing periods? and 2- Which growing periods fruit trees are less sensitive to water stress? Determining the application period of deficit irrigation is necessary for fruit trees (Fereres \& Goldhamer 1990).

Turkey is one of the countries leading apple production with $3.1 \%$ of the world's apple production. Isparta, Niğde, Denizli, Karaman, and Antalya are the leading apple-growing areas. Isparta with almost $20.3 \%$ of country production is a very important apple-growing region of Turkey (TUIKK 2018). The aim of this study was to determine the effects of deficit irrigation treatments on yield, water-yield relations and stomatal conductance. And also; 1) to develop deficit irrigation scheduling in order to save water against water deficit in growing seasons because of the decrease in available water resources, 2) to determine the most suitable treatment.

\section{Material and Methods}

\subsection{Study area and plant material}

The experiment was carried out at Fruit Research Institute (Eğirdir, Isparta-Turkey) for 3 years (2010-2012). The study area has a transition climate between the Mediterranean and Central Anatolia. In the study, the Braeburn apple trees grafted on M9 rootstock (planting distance $3.5 \mathrm{~m} \mathrm{x} 1.5 \mathrm{~m}$ ) and planted in the year 2000 were used as the plant material. Some soil characteristics of orchard soils in Table 1.

Table 1- Soil characteristics of the experimental area

\begin{tabular}{ccccccccc}
\hline $\begin{array}{c}\text { Depth } \\
(\mathrm{cm})\end{array}$ & $\begin{array}{c}\gamma \\
\left(\mathrm{g} \mathrm{cm}^{-3}\right)\end{array}$ & $\begin{array}{c}F C \\
(\%)\end{array}$ & $\begin{array}{c}W P \\
(\%)\end{array}$ & $\begin{array}{c}A W H C \\
(\mathrm{~mm})\end{array}$ & $\begin{array}{c}\text { Salinity } \\
\left(\mathrm{dS} \mathrm{\textrm {m } ^ { - 1 } )}\right.\end{array}$ & $p H$ & $\begin{array}{c}\text { Organic matter } \\
(\%)\end{array}$ & Texture \\
\hline $0-30$ & 1.46 & 24.20 & 11.50 & 55.60 & 0.175 & 8.1 & 1.80 & Clay loam \\
$30-60$ & 1.38 & 25.10 & 13.10 & 49.70 & 0.125 & 7.9 & 2.70 & Clay loam \\
$60-90$ & 1.41 & 24.30 & 12.20 & 51.20 & 0.130 & 8.0 & 2.75 & Clay loam \\
\hline
\end{tabular}

$\gamma$, unit weight of soil. Field capacity and Wilting point at $0-90 \mathrm{~cm}$ soildepthare 312.7 and $156.2 \mathrm{~mm}$ respectively; AWHC, available water holding capacity

\subsection{Irrigation treatments}

A pump was used to supply the irrigation water from an irrigation canal and it was applied with drip irrigation system. Each irrigation treatment had a water meter in order to measure the irrigation water volume. Main pipe diameters, emitter spacing and flow rate were calculated according to Y1ldırım (2005). For drip irrigations, two 16 $\mathrm{mm}$ diameter lateral pipes with in-line pressure compensated emitters were used for each tree row. Emitter spacing and discharge rate were $50 \mathrm{~cm}$ and $4 \mathrm{lh}^{-1}$, respectively. One mini valve was installed at each lateral input to control the irrigation water volume. Digital tensiometers were used to measure soil moisture at soil depths (30, 60, and 90 $\mathrm{cm}$ ) (Soilspec digital tensiometer, JGK TECH, Australia) before each irrigation in each treatment and replication. One tree was selected for each replication and tensiometers were placed perpendicularly between two lateral lines under canopy of apple tree.

Six different irrigation treatments were applied as $\mathrm{I}_{1}$; non-deficit program, $\mathrm{I}_{2}$; continuous deficit irrigation program $(\mathrm{CDI}), \mathrm{I}_{3}$; deficit irrigation program between the $40^{\text {th }}$ and $70^{\text {th }}$ days after full bloom (DAFB), $\mathrm{I}_{4}$; deficit irrigation program between the $70^{\text {th }}$ and $100^{\text {th }}$ DAFB, $I_{5}$; deficit irrigation program between the $100^{\text {th }}$ and $130^{\text {th }}$ DAFB and $\mathrm{I}_{6}$ deficit irrigation program between the $130^{\text {th }}$ and $160^{\text {th }}$ DAFB. Full bloom dates of the Braeburn apple variety were April $21^{\text {st }}, 20^{\text {th }}$, and $22^{\text {nd }}$ in 2010,2011 , and 2012 , respectively. Irrigation interval for all treatments was used as 4 days. The pan coefficient $\left(K_{p}\right)$ to be used for determining the irrigation water volume to be applied was considered as 1.0 and 0.25 for $\mathrm{I}_{1}$ and $\mathrm{I}_{2}$ respectively during the whole vegetation period. During the deficit irrigation periods, for $\mathrm{I}_{3}, \mathrm{I}_{4}, \mathrm{I}_{5}$, and $\mathrm{I}_{6}$ treatments, $\mathrm{K}_{\mathrm{p}}$ was considered as 0.25 . However, out of the deficit irrigation periods, $\mathrm{K}_{\mathrm{p}}$ was considered as 1.0. Deficit irrigation periods were selected as 30 days due to the fact that the phenological separation of apple fruit and shoot development is not clear unlike some other fruit varieties such as 
pear and peach (Forshey et al 1983; Chalmers 1989). Short-term water deficit applications $\left(\mathrm{I}_{3}, \mathrm{I}_{4}, \mathrm{I}_{5}\right.$, and $\left.\mathrm{I}_{6}\right)$ were launched after the $40^{\text {th }}$ DAFB. The cell division phase of apples is effective on fruit size and lasts for 4-5 weeks after full bloom (Felmann 1996). At the end of the $4^{\text {th }}-5^{\text {th }}$ weeks after full bloom, the phase of fruit cell division is accepted to be completed. Therefore, short-term water deficit applications were initiated following these days.

\subsection{Irrigation water, evapotranspiration and WUE}

Irrigation water, I, was calculated in each treatment according to Equation (1) and (2) (Ertek \& Kanber 2003).

$\mathrm{I}=\mathrm{E}_{\mathrm{pan}} \mathrm{X} \mathrm{K}_{\mathrm{p}} \times \mathrm{P}$

In Equation; $\mathrm{I}$, is the amounts of irrigation water $(\mathrm{mm}) ; \mathrm{E}_{\mathrm{pan}}$, the cumulative pan evaporation at 4-day irrigation interval $(\mathrm{mm}) ; \mathrm{K}_{\mathrm{p}}$, pan coefficient; $\mathrm{P}$, shaded area, $37 \%(0.37)$. Percentage of the shaded area was calculated as the ratio of the surface area shaded by trees at noon to the surface area allocated to one tree and found to be $37 \%$ (0.37). Thus, only the $37 \%$ of the total cropped area was irrigated. Evaporation was measured every day by using a Class-A pan. Calculated irrigation water according to Equation (1) was converted to total irrigation volume by using Equation (2).

$I_{v}=I \times A$

Where; $I_{v}$ is the total irrigation water volume (liter), $I$ is the irrigation water $(\mathrm{mm}), A$ is the plot area per treatment including replications $\left(\mathrm{m}^{2}\right)$. Programmed irrigation applications were initiated after the available moisture at 0-90 cm soil depth reached to field capacity at the end of the full bloom. The first and last irrigation dates were May $14^{\text {th }}-$ September $27^{\text {th }}$, May $8^{\text {th }}-$ September $25^{\text {th }}$, and May $14^{\text {th }}-$ September $23^{\text {rd }}$, respectively for 2010 , 2011, and 2012. Evapotranspiration (ET) was calculated by using soil water balance method (Equation (3)) (James 1988).

$\mathrm{ET}=\mathrm{I}+\mathrm{R}+\mathrm{C}_{\mathrm{r}}-\mathrm{D}_{\mathrm{p}}-\mathrm{R}_{\mathrm{f}} \pm \Delta \mathrm{s}$

In equation; ET, the evapotranspiration $(\mathrm{mm}) ; \mathrm{I}$, the irrigation water amounts $(\mathrm{mm}) ; \mathrm{R}$, the rainfall $(\mathrm{mm}) ; \mathrm{C}_{\mathrm{r}}$, the capillary rise $(\mathrm{mm}) ; \mathrm{R}_{\mathrm{f}}$ is the surface run-off $(\mathrm{mm}) ; \mathrm{D}_{\mathrm{p}}$, the water loss by deep percolation $(\mathrm{mm}) ; \Delta \mathrm{s}$, the change in profile soil water content $(\mathrm{mm}) . \mathrm{C}_{\mathrm{r}}$ and $\mathrm{R}_{\mathrm{f}}$ were zero, since the experimental area had not any ground water problems and emitter discharge rate was selected in accordance with infiltration rate. Precipitation was measured after every rainy day by using a pluviometer which was near the study area. Equation (4) was used to calculate water use efficiency (WUE) for all treatments (Howell et al 1990).

$\mathrm{WUE}=(\mathrm{Y} / \mathrm{ET}) \times 100$

Where; water use efficiency, WUE $\left(\mathrm{t} \mathrm{ha}^{-1} \mathrm{~mm}^{-1}\right)$, yield, $\mathrm{Y}\left(\mathrm{t} \mathrm{ha}^{-1}\right)$, and ET is the evapotranspiration (mm).

\subsection{Yield response factor}

Yield response factor $\left(\mathrm{k}_{\mathrm{y}}\right)$ of each treatment was calculated according to Equation (5) (Doorenbos et al 1986; Steduto et al 2012).

$\left[1-\left(\mathrm{Y}_{\mathrm{a}} / \mathrm{Y}_{\mathrm{m}}\right)\right]=\mathrm{k}_{\mathrm{y}} \mathrm{x}\left[1-\left(\mathrm{ET}_{\mathrm{a}} / \mathrm{ET}_{\mathrm{m}}\right)\right]$

Where; $\mathrm{Y}_{\mathrm{a}}$ is the yield of the treatment, which $\mathrm{k}_{\mathrm{y}}$ is calculated $\left(\mathrm{t} \mathrm{ha}^{-1}\right), \mathrm{Y}_{\mathrm{m}}$ is the yield of $\mathrm{I}_{1}$ treatment (nondeficit conditions, $\left.\mathrm{t} \mathrm{ha}^{-1}\right), \mathrm{ET}_{\mathrm{a}}$ is the evapotranspiration of the treatment, which $\mathrm{k}_{\mathrm{y}}$ is calculated $(\mathrm{mm}), \mathrm{ET}_{\mathrm{m}}$ is the evapotranspiration of $\mathrm{I}_{1}$ treatment (non-deficit conditions, $\mathrm{mm}$ ), and the yield response factor is $\mathrm{k}_{\mathrm{y}}$.

\subsection{Other measurements}

Yield: Five trees were harvested in the middle of the experimental plot and all them were weighted. So the yield was determined as $\mathrm{t} \mathrm{ha}^{-1}$. Dates of harvest were October $18^{\text {th }}, 24^{\text {th }}$, and $22^{\text {nd }}$ in 2010,2011 , and 2012, respectively. 
Stomatal conductance (SC): Stomatal conductance measurements were carried out on the trees with porometer (Delta-T, Porometer-AP4). Leaf samples were taken from the sun-exposed mature leaves of one year old shoots from different sides of the selected trees in every treatment. At least 5 leaves per tree were sampled, and two repetitive readings were taken from each leaf.

\subsection{Experimental design and statistical analysis}

Experiments were carried out in Randomized Blocks Experimental Design with three replications. Each treatment had three replications and there were two rows apple trees in each replication. Each row had 9 trees. One row in each replication was left as extra row between two replications. Only five trees in one row were considered for calculating yield and the other measurements. Therefore, all measurements and harvests were conducted on 5 trees in each replication. The analysis of variance (ANOVA) test was calculated with JUMP software (SAS Institute Inc.) for the data. The differences among treatments were compared by using LSD test.

\section{Results and Discussion}

\subsection{Irrigation water and evapotranspiration}

The total evapotranspiration and irrigation water values are given in Table 2. The highest evapotranspiration in growing period of apple occurred in 2012 because seasonal average air temperature was higher than the other years (Figure 1). The pan evaporation values in 2012 was also higher than the others (Table 2). The soil water content (SWC) measured at $90 \mathrm{~cm}$ soil depth before each irrigation for all treatments during the study (Figure 2). The irrigation water compensated the plant water consumption in all treatments until the $72^{\text {nd }} \mathrm{DAFB}$, and then the soil moisture in the effective root zone started to decrease due to increasing air temperature (July and August) and rapid fruit development period (Stage II) (Atay 2007). Since the irrigation water did not compensate the plant water consumption under deficit conditions, trees consumed the available soil moisture. Similar to $\mathrm{I}_{2}$, the soil water content decreased quickly because of the rapid fruit development stage (Stage II).

Table 2- Total evapotranspiration (ET) and irrigation water (I) of study

\begin{tabular}{|c|c|c|c|c|c|c|}
\hline \multirow[b]{2}{*}{ Treatments } & \multicolumn{2}{|c|}{2010} & \multicolumn{2}{|c|}{2011} & \multicolumn{2}{|c|}{2012} \\
\hline & $\begin{array}{c}I \\
(\mathrm{~mm})\end{array}$ & $\begin{array}{c}E T \\
(\mathrm{~mm})\end{array}$ & $\begin{array}{c}I \\
(\mathrm{~mm})\end{array}$ & $\begin{array}{c}E T \\
(\mathrm{~mm})\end{array}$ & $\begin{array}{c}I \\
(\mathrm{~mm})\end{array}$ & $\begin{array}{c}E T \\
(\mathrm{~mm})\end{array}$ \\
\hline $\mathrm{I}_{1}$ & 363.8 & 480.8 & 361.2 & 478.0 & 395.0 & 522.7 \\
\hline $\mathrm{I}_{2}$ & 118.4 & 267.4 & 107.8 & 243.9 & 119.3 & 287.7 \\
\hline $\mathrm{I}_{3}$ & 317.1 & 426.2 & 308.7 & 420.7 & 335.0 & 465.9 \\
\hline $\mathrm{I}_{4}$ & 296.5 & 418.3 & 292.4 & 416.9 & 312.6 & 475.8 \\
\hline $\mathrm{I}_{5}$ & 287.3 & 412.8 & 300.8 & 448.2 & 320.2 & 492.9 \\
\hline $\mathrm{I}_{6}$ & 318.7 & 431.9 & 316.6 & 454.8 & 349.3 & 500.6 \\
\hline $\mathrm{E}_{\text {pan }}(\mathrm{mm})$ & \multicolumn{2}{|c|}{890.1} & \multicolumn{2}{|c|}{909.9} & \multicolumn{2}{|c|}{984.8} \\
\hline $\mathrm{P}(\mathrm{mm})$ & \multicolumn{2}{|c|}{80.5} & \multicolumn{2}{|c|}{87.2} & \multicolumn{2}{|c|}{114.9} \\
\hline
\end{tabular}

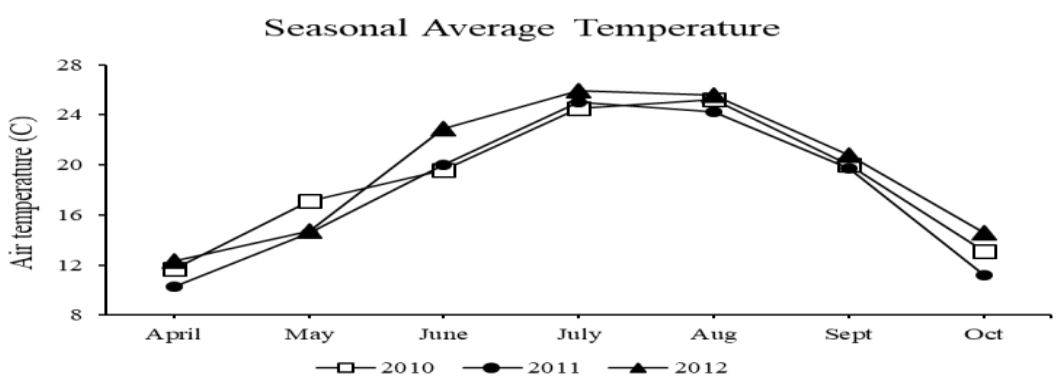

Figure 1- Seasonal average air temperature of the experimental area

Different deficit irrigation treatments were effective on the $I$ and $E T$ because of decreasing available water at effective root zone of apple trees (Mills et al 1997; Petillo et al 2009). Less irrigation water was applied to CDI $\left(\mathrm{I}_{2}\right)$ during vegetation period. Trees in that treatment consumed less water. The amount of plant water consumption 
decreased in $\mathrm{I}_{3}, \mathrm{I}_{4}, \mathrm{I}_{5}$, and $\mathrm{I}_{6}$ treatments during water deficit periods. When compared to $\mathrm{I}_{1}$, water saving ranged from 12.4 to $19.7 \%$ in 2010 , from 12.4 to $18.9 \%$ in 2011 , and from 11.6 to $20.9 \%$ in 2012 . The highest water saving was determined in $\mathrm{I}_{4}$ and $\mathrm{I}_{5}$, which included deficit irrigation during the period of higher evaporation. The deficit irrigation applied between the $70^{\text {th }}$ and $100^{\text {th }}$ and between the $100^{\text {th }}$ and $130^{\text {th }}$ DAFB resulted in a decrease in the need for irrigation water in apple growing. In deficit irrigation treatments, plant water consumption decreased as the amount of irrigation water decreased. One of the periodic deficit irrigation programs mentioned in this study can be applied for water saving in growing season. However, yield should be a criterion on selection. Therefore, before mentioned factors should be taken into consideration while making suggestion to growers. In recent years, a decrease has been encountered in available water resources due to lack of precipitation and drought. Such a case is more apparent especially in the Mediterranean Basin and leads to serious water shortage (Lo Bianco et al 2012). Thus, the treatments that include water saving in growing season become even more important.

The duration of Stage I in which fruit development is slow, is 56 days after DAFB for Braeburn apple variety in Eğirdir region. Stage II is 95 days after Stage I (Atay 2007). The water content in root zone was in compliance with the fruit development rate. Roots consumed the available water in soil, and a decrease in water content was then observed in all treatments with the beginning of Stage II.
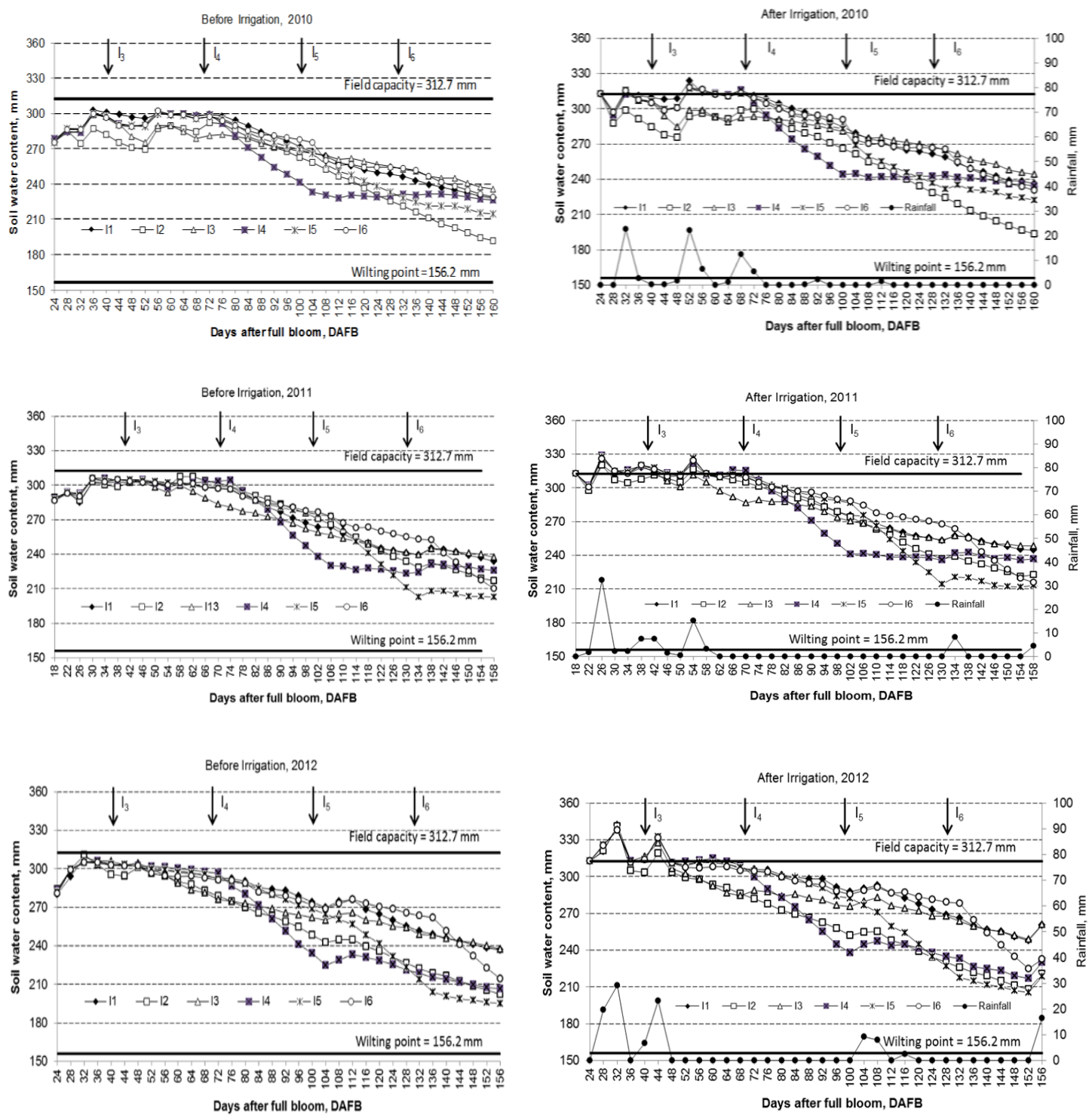

Figure 2- The soil water content at initiation and after irrigations 


\subsection{Stomatal conductance}

Stomatal conductance $\left(\mathrm{g}_{\mathrm{s}}\right.$ ) was higher in $\mathrm{I}_{1}$ (non-deficit irrigation) but the lowest in $\mathrm{I}_{2}$ (CDI) during the growth period (Figure 3). Stomatal conductance values in other treatments during the period of deficit irrigation were close to those of $\mathrm{I}_{2}$. Following the end of deficit period, an evident increase in $\mathrm{g}_{\mathrm{s}}$ values was observed. Talluto et al (2008) and Lo Bianco \& Francaviglia (2012) reported that, compared to other treatments, deficit irrigation caused a decrease in $\mathrm{g}_{\mathrm{s}}$. Decreased $\mathrm{g}_{\mathrm{s}}$ in DI trees often occurred as a result of soil water deficit (Mpelasoka et al 2001). Talluto et al (2008) stated that this effect should be due to relatively rapid soil drying and consequent hormonal signal. Some studies conducted on potted apples, olive and grapes have similar results with this study (Dry \& Loveys 1999; De Souza et al 2003; Wahbi et al 2005). When the plant is exposed to water stress as a result of a decrease in available soil water at root zone, it closes its stomas so as to decrease evaporation from the leaf area. The closure of stomas may also occur as a result of ABAs existing in roots and produced and transferred from shoots. The closure of stomas may be regarded as a defense mechanism against drought. ABA is highly effective on the closure of stomas. Its accumulation in leaves plays a crucial role in decreasing loss of water by transpiration under stress conditions (Taiz \& Zeiger 1998). In this study, ABA was not measured. However, the decrease in $\mathrm{g}_{\mathrm{s}}$ values in water deficit periods can be explained in this way.

The difference between $g_{s}$ values was significant $(\mathrm{P}<0.01)$ in two years. According to the results of $\mathrm{g}_{\mathrm{s}}$ measurements, it could be said M9 rootstock apple trees are affected by short-term water stress but recovered from the effects of stress as soon as stress conditions ended.
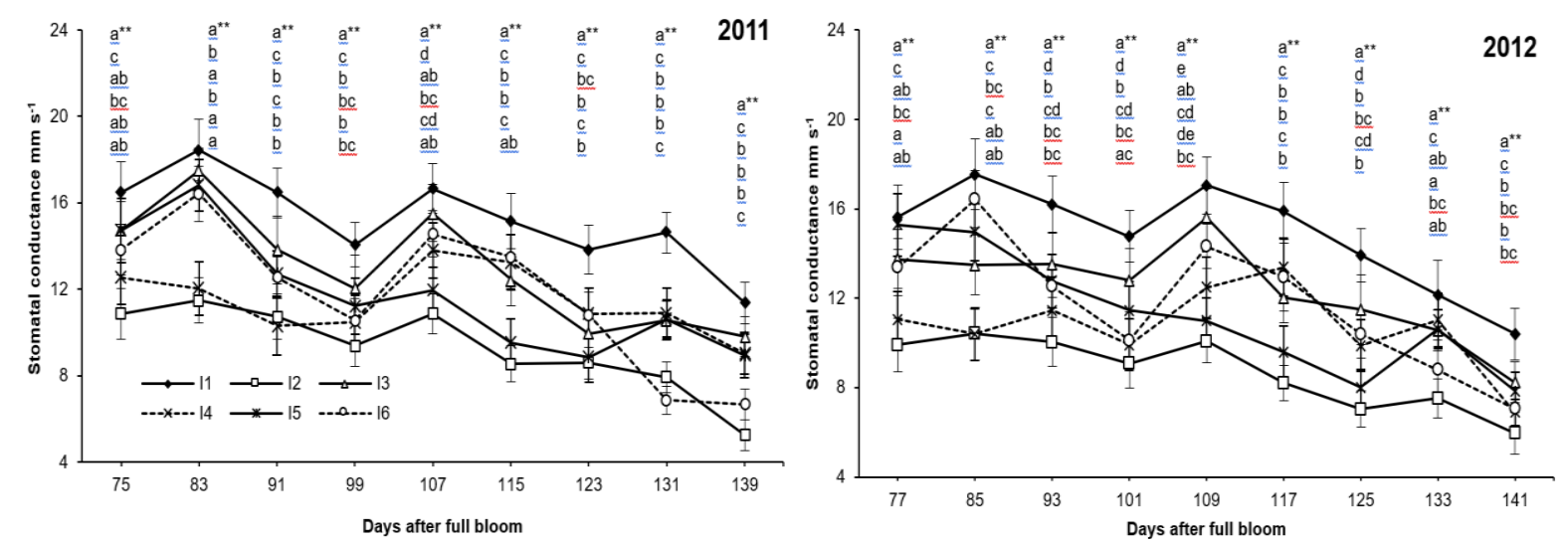

Figure 3- Stomatal conductance of treatments in 2011 and 2012 (Values with common letters do not differ significantly in each separate column $(* * \mathbf{P}<0.01))$

\subsection{Yield}

The yield obtained from 2012 was more than other years. Apple trees is very sensitive to climatic events like water stress, heat stress, heavy precipitation, and etc. during blossom period (Bekey et al 1981). The first and second years of the experiment had some climate events mentioned above. They had negative effects on fruit set and fruit numbers and the yield decreased. But climate conditions in third year was more suitable than first years of the experiment for blossom period and fruit set. That's why yield increased according to 2010 and 2011. But deficit irrigation treatments $\left(I_{3}, I_{4}, I_{5}\right.$ and $\left.I_{6}\right)$ had less yield than $I_{1}$ as in 2010 and 2011.

The effect of treatments on yield was significant $(\mathrm{P}<0.01)$ for 3 years (Table 3 ). The yield was affected less in $\mathrm{I}_{3}$ than it was in other deficit irrigation treatments. It was determined that $\mathrm{I}_{3}$ had less negative effects on yield in this study. The yield in $\mathrm{I}_{3}$ was closes to that in $\mathrm{I}_{1}$ and declined by $6 \%$ and $11 \%$. As an average over three years, a yield decrease of $10 \%, 18 \%, 18 \%$, and $13 \%$ was observed in $\mathrm{I}_{3}, \mathrm{I}_{4}, \mathrm{I}_{5}$, and $\mathrm{I}_{6}$, respectively, compared to $\mathrm{I}_{1}$. While CDI caused 34\% and 38\% reduction in yield in 2010 and 2011, it reached 55\% in 2012. The transportation effect of water deficit on apple tree development and yield could be determined in subsequent years (Doorenbos et al 1986). Girona et al (2010a) also reported that higher water stress during the late development period of apple trees led to yield reduction in development process of the next year. 
Table 3- The yield values obtained from treatments

\begin{tabular}{|c|c|c|c|c|c|c|}
\hline \multirow[b]{2}{*}{ Treatments } & \multicolumn{2}{|c|}{2010} & \multicolumn{2}{|c|}{2011} & \multicolumn{2}{|c|}{2012} \\
\hline & $\begin{array}{c}\text { Yield } \\
\left(t h a^{-1}\right)\end{array}$ & $\begin{array}{c}\text { Decrease in } y i \\
(\%)\end{array}$ & $\begin{array}{c}\text { Yield } \\
\left(t h a^{-1}\right)\end{array}$ & $\begin{array}{c}\text { Decrease in yield } \\
(\%)\end{array}$ & $\begin{array}{c}\text { Yield } \\
\left(t h a^{-1}\right)\end{array}$ & $\begin{array}{c}\text { Decrease in yield } \\
(\%)\end{array}$ \\
\hline $\mathrm{I}_{1}$ & $58.8 \mathrm{a}^{* *}$ & 0.0 & $61.1 \mathrm{a}^{* *}$ & 0.0 & $71.7 \mathrm{a}^{* *}$ & 0.0 \\
\hline $\mathrm{I}_{2}$ & $38.9 \mathrm{~d}$ & 33.8 & $37.6 \mathrm{c}$ & 38.5 & $32.2 \mathrm{c}$ & 55.1 \\
\hline $\mathrm{I}_{3}$ & $55.2 \mathrm{ab}$ & 6.1 & $54.1 \mathrm{ab}$ & 11.5 & $63.8 \mathrm{ab}$ & 11.0 \\
\hline $\mathrm{I}_{4}$ & $50.4 \mathrm{bc}$ & 14.3 & $48.5 \mathrm{~b}$ & 20.6 & $58.0 \mathrm{~b}$ & 19.1 \\
\hline $\mathrm{I}_{5}$ & $46.7 \mathrm{c}$ & 20.6 & $51.7 \mathrm{~b}$ & 15.4 & $58.1 \mathrm{~b}$ & 19.0 \\
\hline $\mathrm{I}_{6}$ & $51.8 \mathrm{bc}$ & 11.9 & $53.1 \mathrm{~b}$ & 13.1 & $62.1 \mathrm{ab}$ & 13.4 \\
\hline
\end{tabular}

**, $\mathrm{P}<0.01$, Values with common letters do not differ significantly in each separate column

Deficit irrigation treatments had lower yield than non-deficit treatment. It was reported that deficit irrigation applications reduced yield in apple because available water at effective root zone was less than no-deficit irrigation treatment (Mpelasoka et al 2001; Petillo et al 2009; Girona et al 2010b). Available water in soil is very important for root activity. The irrigation water applied to treatments affects the available water in soil to be used by apple trees and consequently plant water balance and yield (Naor et al 1997). Amounts of available soil water were very different because of different irrigation water amounts applied to treatments in this study. The yield of deficit irrigation treatments was less than no-deficit irrigation treatment in this study like related other studies. Apple trees grafted on M9 rootstock had shallow root system, and thus they were sensitive to soil moisture reduction (Ferre \& Carlson 1987). Different yields were obtained from the treatments because different irrigation water amounts were applied in this study. The yield obtained from treatments was closely associated with the irrigation water amounts and evapotranspiration.

\subsection{Water use efficiency and Ky}

WUE ranged between 0.112 and $0.154 \mathrm{tha}^{-1} \mathrm{~mm}^{-1}$ during the study (Table 4). The irrigation treatment having the lowest water consumption $\left(\mathrm{I}_{2}\right)$ gave the highest results for the first two years but the lowest WUE in the third year. The reason may be that the stress conditions of the first two years affected the third year. Apart from that, the highest values were found in $\mathrm{I}_{3}$. In other periodic deficit irrigation treatments, however, values were close to each other. The reason why the WUE values of $\mathrm{I}_{4}, \mathrm{I}_{5}$, and $\mathrm{I}_{6}$ were lower than those of $\mathrm{I}_{1}$ may be that the water deficit of those periods affected yield negatively. Some researchers reported a lower WUE values in commercial irrigation treatments than in deficit irrigation treatments in fruit trees (Mitchell \& Chalmers 1982; Zegbe \& Behboudian 2008; Girona et al 2010b). This study has a different result.

Table 4- Water use efficiency (WUE) of irrigation treatments in 2010, 2011, and 2012

\begin{tabular}{cccc}
\hline \multirow{2}{*}{ Treatments } & \multicolumn{3}{c}{ WUE $\left(t \mathrm{ha}^{-1} \mathrm{~mm}^{-1}\right)$} \\
\cline { 2 - 4 } & 2010 & 2011 & 2012 \\
\hline $\mathrm{I}_{1}$ & 0.122 & 0.128 & 0.137 \\
$\mathrm{I}_{2}$ & 0.145 & 0.154 & 0.112 \\
$\mathrm{I}_{3}$ & 0.130 & 0.129 & 0.137 \\
$\mathrm{I}_{4}$ & 0.120 & 0.116 & 0.122 \\
$\mathrm{I}_{5}$ & 0.113 & 0.115 & 0.118 \\
$\mathrm{I}_{6}$ & 0.120 & 0.117 & 0.124 \\
\hline
\end{tabular}

The relationship between relative decrease in yield $\left(1-\left(\mathrm{Y}_{\mathrm{a}} / \mathrm{Y}_{\mathrm{m}}\right)\right)$ and relative decrease in plant water consumption (1-(ET $\left./ \mathrm{ET}_{\mathrm{m}}\right)$ ) for each treatment is shown in Figure 4. The linear equations obtained from 3 years' data for each deficit irrigation treatment were well fitted, since the $r^{2}$ values are between 0.83 and 0.99 . Both the magnitude and the duration of water deficit affect plant yield directly. Under deficit water conditions, compared to higher Ky values, lower $\mathrm{k}_{\mathrm{y}}$ values in whole or partial (independent) plant vegetation periods cause less yield losses (Doorenbos et al 1986). During the study, proportional yield loss corresponding to proportional plant water consumption was at the lowest level in the deficit irrigation treatment between the $40^{\text {th }}$ and $70^{\text {th }}$ days after full bloom $\left(I_{3}\right)$ compared to other deficit irrigation treatments. Yield reduction in apple trees is almost directly consistent to reducing plant water consumption $\left(\mathrm{k}_{\mathrm{y}}=0.97\right)$ in $\mathrm{CDI}\left(\mathrm{I}_{2}\right)$. In this study, both the magnitude and the duration (i.e. 30 days) of the deficit irrigation applications were same in $\mathrm{I}_{3}, \mathrm{I}_{4}, \mathrm{I}_{5}$, and $\mathrm{I}_{6}$. However, the yield of 
apple trees was found more sensitive under the stress conditions between the $70^{\text {th }}$ and $100^{\text {th }}$ days, between the $100^{\text {th }}$ and $130^{\text {th }}$ days, and between the $130^{\text {th }}$ and $160^{\text {th }}$ days compared to the stress conditions between the $40^{\text {th }}$ and $70^{\text {th }}$ days. The other reason of this, fruit growth was slower in $I_{3}$ period than the other deficit periods. Therefore fruit growth may be affected less. Crop response was very sensitive to water deficit $\left(k_{y}>1\right)$ in $I_{6}, I_{5}$, and $I_{4}$, respectively. Ebel (1991) and Girona et al (2010a) also reported that higher water stress during the late development period of apple trees leads to yield reduction in the development process of the following year.

In 2010 , the yield response factor $\left(\mathrm{k}_{\mathrm{y}}\right)$ for $\mathrm{I}_{2}, \mathrm{I}_{3}, \mathrm{I}_{4}, \mathrm{I}_{5}$ and $\mathrm{I}_{6}$ were, respectively, $0.85,0.75,1.23,1.63$, and 0.99 . The values were $0.82,0.81,1.07,1.21$ and 1.40 in 2011 . The corresponding values in 2012 were: $1.25,0.77,1.47$, 2.11 , and 2.11, respectively. $\mathrm{K}_{\mathrm{y}}$ values of $\mathrm{I}_{3}$ treatment were under 1.00 for three years. The increase in $\mathrm{K}_{\mathrm{y}}$ from 2010 to 2012 was $61 \%, 90 \%, 65 \%, 130 \%$ and $171 \%$, respectively in $\mathrm{I}_{2}, \mathrm{I}_{3}, \mathrm{I}_{4}, \mathrm{I}_{5}$ and $\mathrm{I}_{6}$. The reason for this was; although yield and ET were higher in 2012 than 2010, decrease in yield corresponding to per unit water decrease, i.e. response of yield to decrease in evapotranspiration, was higher in 2012 than 2010.

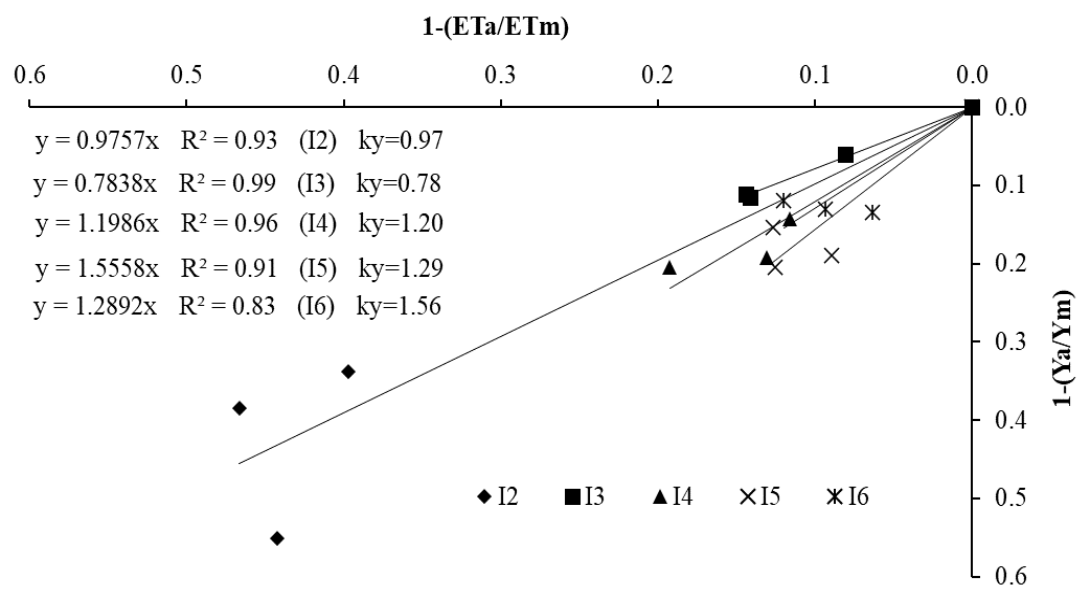

Figure 4- Ky values obtained from apple trees under deficit irrigation practices

\section{Conclusions}

It was obtained that the response of Braeburn apples to deficit irrigation treatments was different. Trees were affected by short-term stress but overcame stress conditions as soon as the deficit irrigation period ended. Of all deficit irrigation treatments, $I_{3}$ gave the highest yield and WUE with water saving. Decrease in the yield of $I_{3}$ with the deficit irrigation applied between the $40^{\text {th }}$ and $70^{\text {th }}$ DAFB was less than that of the other deficit irrigation treatments. Therefore, $I_{3}$ was found to be more suitable than all the other deficit irrigation programs when water scarcity happens since it also ensures water saving.

\section{Acknowledgements}

This experiment was summarized a part of the research project (Project number: BBMB-11-01) funded by the General Directorate of Agricultural Research and Policies of MAF.

\section{References}

Atay E (2007). Determination of fruit growth and development some apple varieties on MM 106 rootstock. Selçuk University Graduate School of Natural and Applied Sciences, MS Thesis, Konya, Turkey, 68 pp (published)

Bekey R S, Burgett D M \& Fisher G C (1981). Pollination and fruit set of apple. Oregon State University Extension Service, Extension Circular number: 1087, pp. 3

Chalmers D J (1989). A physiological examination of regulated deficit irrigation. New Zealand Journal of Agricultural Science 23: $44-48$ 
De Souza C R, Maroco J P, Dos Santos T P, Rodrigues M L, Lopes C M, Pereira J S \& Chaves M M (2003). Partial rootzone drying, regulation of stomatal aperture and carbon assimilation in field-grown grapevines (Vitis vinifera cv. Moscatel). Functional Plant Biology 30: 653-662

Doorenbos J, Kassam A H, Bentvelsen C L M, Branscheid V, Plusje J M G A, Smith M, Uittenbogaard G O \& Van Der Wal H K (1986). Yield Response to Water. FAO Irrigation and Drainage Paper. No: 33, 193 pp

Dry P R \& Loveys B R (1999). Grapevine shoot growth and stomatal conductance are reduced when part of the root system is dried. Vitis 38: 151-154

Ebel R C (1991). Apple tree and fruit response to drought stress. PhD Thesis, Washington State Univ., Pullman (published)

Ebel R C, Proebsting E L \& Evans R G (1995). Deficit irrigation to control vegetative growth in apple and monitoring fruit growth to schedule irrigation. HortScience 30: 1229-1232

Ertek A \& Kanber R (2003). Effects of different irrigation programs on boll number and abscission percentage of cotton. Agricultural Water Management 60(1): 1-11

Felmann J K (1996). Pome fruit quality in relation to environmental stress, In: Maib K M, Andrews P K, Lang G A \& Mullinix K. (Eds.), Tree Fruit Physiology: Growth and Development: A Comprehensive Manual for Regulating Deciduous Tree Fruit Growth and Development, Good Fruit Growers, Yakima, Washington, USA, pp. 127-131

Ferre D C \& Carlson R F (1987). Apple rootstocks. In: Rom, R.C. and R.F. Carlson. (Eds.), Rootstocks for Fruit Trees. John Wiley and Sons, New York, USA, pp. 107-143

Fereres E \& Goldhamer D (1990). Irrigation of deciduous fruit and nut trees. In: Lascano R J \& Sojka R E (Eds.), Irrigation of Agricultural Crops. American Society of Agronomy, pp. 987-1017

Forshey C G, Weires R W, Stanely B H \& Seem R C (1983). Dry weight partitioning of 'McIntosh' apple trees. Journal of the American Society for Horticultural Science 108: 149-154

Girona J, Behboudian M H, Mata M, Del Campo J \& Marsal J (2010a). Exploring six reduced irrigation options under water shortage for 'Golden Smoothee' apple: Responses of yield components over three years. Agricultural Water Management 98: $370-375$

Girona J, Del Campo J, Bonastre N, Paris C, Mata M, Arbones A \& Marsal J (2010b). Evaluation of different irrigation strategies on apple (Malusdomestica). Physiological and productive results. In: $6^{\text {th }}$ International Symposium on Irrigation of Horticultural Crops. November 2-6, Vina del Mar, Chile

Howell T A, Cuenca R H \& Solomon K H (1990). Crop yield response. In: Hoffman, G.J., Howell, T.A., Solomon, K.H. (Eds.), Management of Farm Irrigation Systems, ASAE Monograph, Michigan, pp. 93-122

James L G (1988). Principles of Farm Irrigation System Design, John Wiley and Sons Inc., New York, USA, 593 pp

Lo Bianco R \& Francaviglia D (2012). Comparative responses of 'Gala' and 'Fuji' apple tree to deficit irrigation: Placement versus volume effects. Plant and Soil 357(1-2): 41-58

Lo Bianco R, Talluto G \& Farina V (2012). Effects of partial root zone drying and rootstock vigour on dry matter partitioning of apple trees (Malus domestica cvar Pink Lady). Journal of Agricultural Science Cambridge 150: 75-86

Mills T M, Behboudian M H \& Clothier B E (1997). The diurnal and seasonal water relations, and composition, of 'Braeburn' apple fruit under reduced plant water status. Plant Science 126: 145-154

Mitchell P D \& Chalmers D J (1982). The effect of reduced water supply on peach tree growth and yields. Journal of the American Society of Horticultural Science 107: 853-856

Mpelasoka B S, Behboudian M H \& Green S R (2001). Water use, yield and fruit quality of lysimeter-grown apple trees: responses to deficit irrigation and to crop load. Irrigation Science 20: 107-113

Naor A, Klein I, Doron I, Gal Y, Ben-David Z \& Bravado B (1997). Irrigation and crop load interactions in relation to apple yield and fruit size distribution. Journal of the American Society of Horticultural Science 122: 411-414 
Naor A, Naschitz S, Peres M \& Gal Y (2008). Responses of apple fruit size to tree water status and crop load. Tree Physiology 28: $1255-1261$

Petillo G M, Puppo L, Morales P \& Hayashi R (2009). Young apple trees response to water stress - Early results. ActaHorticulturae 889: 273-280

Steduto P, Hsiao T C, Fereres E \& Raes D (2012). Crop Yield Response to Water. FAO Irrigation and Drainage Paper. No: 66

Taiz L \& Zeiger E (1998). Plant Physiology. $2^{\text {nd }}$ Edition. 792 pp, Sinauer Associates Inc. Publisher, Sunderland, Massachusetts

Talluto G, Farina V, Volpe G \& LoBianco R (2008). Effects of partial root zone drying and rootstock vigour on growth and fruit quality of 'Pink Lady' apple trees in Mediterrane and environments. Australian Journal of Agricultural Research 59: 785-794

TUIK (2018). Apple production of Turkey. Received in November, 14, 2018 from http://tuik.gov.tr/PreTablo.do?alt_id=1001

Van Hooijdonk, B, Dorji M \& Behboudian M H (2004). Responses of 'Pacific Rose' TM apple to partial root zone drying and to deficit irrigation. European Journal of Horticultural Science 69: 104-110

Wahbi S, Wakrim R, Aganchich B, Tahi H \& Serraj R (2005). Effects of partial rootzone drying (PRD) on adult olive tree (Olea europaea) in field conditions under arid climate I. Physiological and agronomic responses. Agriculture, Ecosystems \& Environment 106: 289-301

Yıldırım O (2005). Irrigation Project Design. Ankara University Agriculture Faculty Publishing: 1542, Lesson book: 495, Ankara, $348 \mathrm{pp}$

Zegbe J A \& Behboudian M H (2008). Plant water status, $\mathrm{CO}_{2}$ assimilation, yield, and fruit quality of 'Pacific Rose ${ }^{\mathrm{TM}}$ apple under partial root zone drying. Advances in Horticultural Science 22: 27-32 